By

Miron Mushkat* and Roda Mushkat**

*Visiting Professor, Department of Politics and Public Administration, University of Hong Kong

**Professor, School of Social Sciences and Law, Brunel University and Honorary Professor, Faculty of Law, University of Hong Kong 


\begin{abstract}
The privatization idea may have lost some of its luster in recent years, but it remains relevant in today's socio-economic environment and is pursued consistently in industrialized and industrializing countries alike. Hong Kong has followed the general pattern in a manner reflecting its particular circumstances and its institutional modus operandi. The underlying logic may not appear highly compelling, from a short-term perspective, yet there are sound grounds for approaching the task positively, if viewed from a multi-year standpoint. Rather surprisingly, for such a quintessentially capitalist society, Hong Kong has not confronted the privatization challenge astutely on the political front and has handled it somewhat mechanically in managerial terms. The benefits to the community may have thus been more modest than one could legitimately expect, given the historical backdrop.
\end{abstract}

Key words: Privatization, Liberalization, Competition, Ownership, Divestiture, Efficiency, Distributive Justice, Macroeconomic Stabilization, Public Choice 


\section{THE TRANSFER OF PROPERTY RIGHTS FROM THE PUBLIC TO THE PRIVATE SECTOR IN HONG KONG: A CRITICAL ASSESSMENT}

\section{Introduction}

Hong Kong possesses a number of politico-economic attributes that qualify as rather unique, whether in theory or practice. Perhaps the most noteworthy is its status as a Special Administrative Region of the People's Republic of China (HKSAR), functioning comfortably as an autonomous capitalist enclave on the periphery of a vast country presided over by a Communist Party that operates in an increasingly benign fashion but is by no means ready to abandon authoritarian rule. While initially unnerved by the departure of the colonial administration, rooted in British democratic soil, and the resumption of Chinese sovereignty, the territory has subsequently recovered its composure and is currently flourishing as an international/ regional/ China-focused intermediation center, albeit at times unevenly so and without suppressing altogether long-term anxieties (Meyer 2000).

Another salient characteristic that distinguishes Hong Kong fundamentally from most industrialized countries and equivalent is the deliberate restraint exercised by the government in the economic sphere. This posture has led, according to an ardent supporter of local policy practices, to an institutional configuration allowing private agents to be guided in a highly effective fashion by a system aptly designated as an "automatic corrective mechanism." The latter is portrayed as a process firmly anchored in an essentially free market economy that continuously alters internal costs and prices to bring them quickly into line with costs and prices in the rest of the world. The flexible movement of internal costs and prices, with associated changes in output and employment, brings about internal and external equilibrium at all levels of world trade, and maximum economic growth (Rabushka 1973; Rabushka 1976; Rabushka 1979; de Mesquita, Newman, and Rabushka, 1985; de Mesquita, Newman, and Rabushka 1996). This disciplined policy setting has been succinctly delineated by the author extolling the virtues of the model:

In Hong Kong, economic affairs are conducted in an environment of almost unfettered free enterprise. Government policy has long dictated a virtually 
hands-off approach toward the private sector, an approach that seems well suited to Hong Kong's exposed and dependent economic and political situation. The philosophy that underlies government in Hong Kong can be summed up in a few short phrases: law and order, minimum interference in private affairs, and the creation of an environment conducive to profitable investment. Regulatory economic controls are held to a minimum, no restrictions are placed on the movement of capital, little protection and few subsidies are given to industry, and the few direct services provided by the government are operated on a commercial basis (Rabushka 1979: 44).

And the adaptability and dynamism that the policy gives rise to have been neatly captured by another scholar:

The government asserts that the Hong Kong economy is a self-regulating one: it is the classical economists' dream. There is therefore no need for the government to intervene. The essence of the argument is that nowhere else in the world is the wage/price flexibility so high as it is in Hong Kong. When a recession occurs, either from a fall in world trade or a decline in the construction industry, output and employment will fall as in the case of a recession in other countries. But, unlike other countries, the response of the Hong Kong economy to such a fall in employment and output will be fast. Such a response takes the form of a decrease in real wages followed by a decrease in prices, as predicted in the classical macroeconomic model. As most of our manufactured goods are for export, the fall in prices will make our products more competitive in overseas markets. In this way, our exports and manufacturing output can be stimulated through this automatic mechanism. Moreover, it can also be argued that the fall in prices and wages will have the effect of increasing the real cash balance (i.e., the cash in the hands of the public in terms of constant prices). Any increase in the real cash balance will tend to make people feel richer than before and, in consequence, consumption will be stimulated and the recovery from a recession will be initiated (Chen 1984: 40).

This spirited depiction of the policy thrust and its impact on system-wide performance has not gone unchallenged. Mildly dissenting views have been offered periodically, highlighting selectively the descriptive limitations of the picture constructed and its normative connotations. The reservations expressed by writers focusing on the normative side initially reflected Keynesian-style and broader liberal concerns about the implications of such a distinctly non-interventionist government stance and heavy reliance on market forces. It was argued that macroeconomic stabilization should be pursued with greater determination, where appropriate, and that strategies should be implemented, in a sensible fashion, to address micro-level market failure and 
economic deprivation/ inequality (Cheng 1982; Chen 1984; Peebles 1988; Ho and Chau 1989).

The somewhat critical observations offered regarding the descriptive side have highlighted the divergences between the "ideal" - perhaps even to a certain extent ideologically-inspired - model and prevailing realities, albeit without overstating the broad implications of any such divergences. In the early stages of the evolution of the "debate" on the role of the government in the economy, students of the Hong Kong scene not firmly attached to laissez-faire principles sought to establish, at least in general terms, that the local authorities did not always follow practices entirely consistent with their own stated strategic tenets or operate at all times in a manner often attributed to them admiringly by others. Specifically, it was pointed out that the government did not adopt an unambiguously passive posture but had explicitly pursued a policy of "positive non-interventionism," endeavoring to enhance the working of market forces and taking complementary actions when necessary (Cheng 1982; Youngson 1982). This moderately revisionist fine-tuning did not culminate in any radical conclusions, yet the emphasis shifted from absolute values to relative ones:

One may, of course, quibble and complain that this is a weak and defective laissez-faire, since it has been contaminated by some concerns of present-day welfare. On the other hand, it is still as close to the real thing as one can come. If Hong Kong no longer boasts as much freedom as $18^{\text {th }}$ century England or the free-wheeling days of $19^{\text {th }}$ century Shanghai, it is still a far throw from the mixed economies of the West today, let alone socialist or communist regimes. Let us say it is early $20^{\text {th }}$ century laissez-faire, although its critics might dispute the fact that it has got so far. In some ways, it is even an improved form, as compared with the more spontaneous laissez-faire of earlier times, for the Hong Kong Government is following the policy consciously and purposefully, taking advantage of the benefits it does offer. But all that does not really matter. If one wishes to find a well-preserved and healthy specimen of an otherwise vanishing species, there is no other place to see and study laissez-faire than Hong Kong (Woronoff 1980: 41).

This re-adjustment of the analytical lens, to reflect the uniqueness of an institutional pattern compared to those witnessed elsewhere rather than its intrinsic merits, was appropriate and well-timed. Nevertheless, it was undertaken at a juncture preceding the emergence of a series of exogenous shocks that have resulted in greater 
government activism at the margin (the influx of immigrants from the mainland, induced by communist rule and Maoist excesses, materialized earlier and provided the catalyst for large-scale public sector supply of housing services). The prospect of British departure and resumption of sovereignty by China, the extreme currency volatility that ensued, leading to the establishment of the "linked exchange rate system"; the prolonged property market bust that crippled domestic demand from the late 1990's to the middle of this decade; the global recession that followed the 2001 equity market collapse; and recurring severe environmental hazards (notably, bird flu and severe acute respiratory syndrome) have compelled the government to adopt counter-cyclical and regulatory measures exceeding the historical norm.

The effects of exogenous shocks do not necessarily dissipate over time. As argued and demonstrated by Peacock and Wiseman (1961), they may become entrenched and, inter alia, affect the long-term balance between the private sector and its public counterpart. The increase in government size witnessed in the past decade or so may partly be explained by invoking their theoretical framework. It may arguably also reflect processes encapsulated in "Wagner's Law," which posits that public expenditure is highly elastic with respect to national income (Bird 1971). Hong Kong's growing affluence may have thus contributed to government expansion. Last but not least, it is possible to hypothesize, along the lines suggested by Baumol (1967), that healthy productivity gains seen in the private domain, in an environment characterized by rapid structural transformation (Sung 1991; Sung 2002), may have boosted the relative share of the economic pie of the inherently less efficient public sector.

It should be emphasized that, at around $20 \%$ of gross domestic product, this share remains distinctly modest by international standards. From a comparative perspective, Hong Kong continues to stand out as an externally open and internally unshackled economic entity, whose government does not make substantial claims on societal resources (Peebles 1988; Ho and Chau 1989; Mushkat 1990; Lethbridge and $\mathrm{Ng}$ 2000). Nevertheless, the persistent rise in public spending, particularly during a period characterized by moderate private sector activity, and government propensity to broaden its role both generally and in specific policy areas have prompted an analytical re-orientation away from "excessive" bureaucratic restraint in the face of 
macro and micro strains toward "overzealousness" in seeking to solve problems/capitalize on opportunities and the lack of discipline exhibited in the process. This new trend has been reinforced by concerns about potentially chronic fiscal deficits, serious challenges posed by aging, and possible post-1997 erosion of commitment to the strict management principles espoused by the colonial administration (Lethbridge and Ng 2000; Ash et al. 2003).

The corollary is that the phenomenon of "government failure" and potential responses thereto have begun to feature, in one form or another, more prominently in the policy literature than the inefficiencies/inequities that manifest themselves in the private marketplace and the public remedies assumed to be necessary to alleviate them (Scott and Burns 1988; Cheek-Milby 1995; Scott 2000; Lo 2002; Mushkat and Mushkat 2003; Mushkat and Mushkat 2004; Mushkat and Mushkat 2005a; Mushkat and Mushkat 2005b; Mushkat and Mushkat 2005c; Scott 2005). The latter have not receded completely into the background because Hong Kong is confronting a number of very serious environmental challenges. Air pollution is at critical levels, seldom seen in countries/large metropolitan areas in the industrialized world. And bird flu constitutes a latent threat of unthinkable proportions, capable of inflicting massive damage on the territory's socio-economic fabric. Notwithstanding the severity of such problems, policy analysts are increasingly gravitating toward symptoms of malfunctioning in the public sector. This is consistent with the pattern observed in mature democracies and post-authoritarian industrializing countries in the past two decades or so.

The government itself is acutely aware of the need to shrink its size due to the uncertain long-term business outlook, implications of demographic stagnation, fragility of the tax system, constraints imposed by the constitution/Basic Law and linked exchange rate system, ramifications of political reforms (however gradual), and pressures emanating from the grass roots. It seems to have embraced privatization as a strategic goal, albeit subject to various qualifications, and has been progressing toward this goal, although by no means in a determined fashion. Independent policy analysts, particularly those with neoclassical economic leanings (the local equivalent of the "Chicago School"), have both encouraged and endorsed the move. The purpose of this paper is to offer some broad insights into the privatization process in 
Hong Kong, place it in the appropriate theoretical context, and highlight its possible shortcomings.

\section{Overview and Evaluation}

The impression is that Hong Kong has a rather crowded privatization agenda. The underground rail network (Mass Transit Railway Corporation; MTRC) has been partially privatized with considerable fanfare and the (fully corporatized) overground rail network (Kowloon-Canton Railway Corporation; KCRC) is expected to be absorbed into it before long. There has also been selective privatization and commercialization of public housing in the territory. Two other initiatives worth highlighting are the establishment of the Hospital Authority (HA), an "independent" organization responsible for managing all public hospitals in the territory (it remains formally accountable to the government through the Secretary for Health and Welfare), and the Electrical and Mechanical Services Trading Fund, an entity which operates as an integral part of the bureaucratic machinery but on a commercial basis (this qualifies as a variant of "contracting in," as distinct from "contracting out").

The Water Supplies Department, International Airport, Post Office (known as Hong Kong Post) are high-profile candidates for privatization at some future juncture. In fact, the airport already functions along the lines of the public hospital system by virtue of being overseen by a body (the Airport Authority; AA) structured in a similar manner to the HA. Given this configuration, it is likely to be privatized much earlier than the other two arms of the government apparently destined to be ultimately decoupled from the public sector. It should also be noted that the government has liberalized a number of key industries, most notably the telecommunications sector. While this does not necessarily amount to "privatization" in local terms, the distinction is often blurred in the international academic/professional literature. There has been a clamor in independent policy circles for broadening the deepening the process (Kwong 1988; Kwon 1990; Mueller 1991; Hall 1996; Cheng and Wong 1997; Ho 1997; Lam 1997; Lam and Chan 1997; Cheng and Wu 1998; Wong 1998; Lam and Chan 2000; Jao 2001). 
Although privatization has been pursued with a degree of consistency, across a potentially wide organizational spectrum, it is necessary to draw a clear distinction in this context between strategic intentions, which are not entirely transparent and yet can tentatively be ascertained, and policy realities, as observed on the ground. Whatever the ultimate vision, in practice privatization has evolved at a leisurely pace and in a piecemeal fashion. The program has not been driven with a great sense of determination and the steps taken do not seem to have been closely interconnected. The record to date is rather modest insofar as the scope of the endeavor is concerned and the consequent changes in the institutional infrastructure. Hong Kong has no compelling reason to opt for New Zealand-style radical surgery, but it has apparently chosen to address the task cautiously and pragmatically, rather than boldly and comprehensively.

With the possible exception of housing (Brewer and La Grange, 2001), privatization also cannot be said to have emerged as an issue that commands much public attention and is constantly propelled into the center of the political arena. Social scientists differentiate between "systematic" and "governmental" agendas. The former consist of matters acknowledged by members of the community as relevant and meriting an appropriate response on the part of the public authorities. The latter refer to problems that are recognized by government officials (including legislators) as such. Systematic agendas normally "percolate" in society, waiting to be elevated to "active" status (Cobb and Elder 1983). Privatization in Hong Kong has not followed that route. It has been embraced by the bureaucracy, albeit not unambiguously, without first gaining shape in "noninstitutional" settings.

This pattern does not correspond to the "pluralist" model of public agenda setting, which assumes that power rests with mobilized citizen groups (Cobb and Elder 1983). Rather, it displays features associated with the "elitist" model, whose proponents argue that power is concentrated in the hands of the few. The latter wield authority over a multitude lacking ready access to the corridors of power. The political structure resembles a pyramid, with authority flowing from the top to the bottom, not the other way around (Dye and Ziegler 1981). The elitist model may be broadened and rendered more flexible by drawing a distinction between administrative (i.e. bureaucratic) and political (i.e., legislative) elites, as well as allowing for an input 
from special interests, as the "subgovernmental" model (Carter 1965). It may offer a more accurate picture of the privatization process in Hong Kong, provided no strong emphasis is placed on the role of legislators (Cheek-Milby 1995).

There is no evidence of a concerted effort to seriously engage the public, or segments thereof, in a dialogue regarding the transfer of assets to the private sector. The government has an elaborate information management system and employs it in a reasonably effective fashion. Policy initiatives are generally signaled in advance and adequate transparency is maintained throughout the exercise. However, this is not necessarily equivalent to educating the public consistently and thoroughly. Nor does it suggest that measures are taken to widen the decision-making circle and encourage two-way communication flows. This is a subject where technical factors inevitably overshadow strategic/ qualitative ones. Nevertheless, in most industrialized countries/ affluent metropolitan areas, it has been tackled in a somewhat less elitist/ subgovernmental manner. Again, New Zealand stands out in this respect (Bollard and Buckle 1987; Easton 1989; Holland and Boston 1990; Boston 1991; Bollard 1992; Clarke and Pitelis 1993; Anderson and Hill 1996).

Privatization is a broad and elastic concept. It may be defined as "the shifting of a function, either in whole or in part, from the public sector to the private sector (Butler 1991:17). As such, "it involves the increased reliance on private actors and market forces to take over...responsibilities that had in recent decades come to be regarded as properly within the governmental sphere (Feigenbaum, Henig, and Hamnett 1999:1). Definitions of this nature are relied upon to convey the essence of the phenomenon, and are thus helpful, but they do not fully capture its complexity. Privatization has evolved over time into a truly multi-dimensional process whose scope cannot easily be delineated in conventional terms. According to Fiegenbaum, Henig, and Hamnett (1999), for example, it has decision-making, delivery, financing, and responsibility aspects.

This flexible approach recasts privatization as a continuum or, better still, as a concept whose various dimensions may be given more effective expression through finelyhoned typologies than simple statements. The delivery and financing aspects, in particular, come into play in contemporary settings in a way that allows policy 
analysts to generate a greater number of institutional scenarios than traditional definitions can accommodate. The point is that service delivery and financing need not be both either through public or private sector channels. The service may be delivered by a private entity (the provider) but financed by a public one (the payer) or vice versa. In fact, four permutations are possible (Table 1). Privatization may thus feature a shift from public delivery of publicly financed services to private delivery of privately financed ones ("wholesale" privatization). However, the term may also encompass less "ambitious" undertakings such as "contracting out," voucher-type schemes (quadrant 2) and configurations involving private financing of publicly delivered services via user charges (quadrant 3 ).

(Insert Table 1 about here)

Indeed, it is arguable that the definition may be stretched ever further. Specifically, in the academic/professional literature privatization is increasingly equated with liberalization (Ott and Hartley 1991; Adam, Cavendish, and Mistry 1992; Bailey 1995; Bailey 1999; Dollery and Wallis 2001; Bailey 2004). The corollary is that virtually any structural initiative designed to enhance efficiency by loosening market forms/unleashing competitive pressures might qualify as privatization of one sort or another (Table 2). This would include "in-house"/public sector-specific "competitive tendering," "contracting in" and the like. It is debatable whether privatization is a subset of liberalization or whether the distinction between the two processes is blurred. Whichever is the case, it is evident that, in confronting organizational realities, one cannot overemphasize the differences.

(Insert Table 2 about here)

In Hong Kong, privatization is largely identified with a complete structural overhaul, or the transfer of public assets which are exclusively managed by the government on a mostly non-commercial basis to a private company which assumes ownership and exercises control over operations. The transition from one state to the other often takes the form of a two-step process, with corporatization preceding privatization but, broadly-speaking, this is the general pattern. Vouchers receive scant attention and even user charges do not loom large on the policy agenda. Contracting out is also not 
pursued with great vigor. The strategy is thus characterized by a rather narrow focus and traditional-style problem conceptualization.

One qualification may be in order in this context. To the extent that certain types of private infrastructure development and operation may be considered as a variant of contracting out, the activity is by no means relegated to the periphery, at least in the theoretical - as distinct from practical - sense of the term ("Build-Operate-Transfer"/ "BOT" denotes that the private sector designs, finances, builds, and operates the facility over the life of the contract; at the end of this period, ownership reverts to the government; an alternative arrangement is the "Build-Transfer-Operate"/ "BTO" model, where the title transfers to the government upon completion of the construction phase of the project; within the "Build-Own-Operate"/ "BOO" framework, the private sector retains permanent ownership and operates the facility on contract).

By the same token, it is difficult to discern any clear relationship, hierarchical or lateral, between the privatization and liberalization efforts in Hong Kong, although there may be a common strategic denominator. The deregulation of the telecommunications industry remains virtually the sole example of a major revamping of a key segment of private sector activity with a view to exposing it to competitive forces (and, by implication, rendering it more responsive to consumer demand). Electric utilities are the next target of a similar face-lift, given the potential for effective decoupling of production (where economies of scale no longer play a crucial role) from distribution (where "natural" monopolies are likely to be the norm for some time to come). Other important industries, such as port facilities/container handling services and property development, have not even reached that stage. As stated earlier, Hong Kong may be regarded as a beacon of free enterprise, from a comparative perspective, but there is arguably considerable scope for further liberalization in parts of the private sector marked by a high concentration of economic power.

This observation applies with fewer qualifications to the public sector. Modest experiments with contracting in do not really amount to a meaningful institutional redesign geared toward promoting competition. The emergence of semi-autonomous 
"authorities" (in addition to the Airport Authority and Hospital Authority, referred to previously, the Housing Authority is worth mentioning) cannot be overlooked. Such forms of "devolved control" are apparently conducive to efficiency and thus consistent with the pursuit of consumer-responsive government. However, it is interesting to note that, unlike in other countries, notably the United Kingdom, no full-fledged "internal markets" have been introduced in areas such as health care (an internal market involves three principal features: the creation of explicit and separate roles for purchasing and supply of services; the establishment of internal quasicontracts and trading arrangements between these separate roles; and the development of accounting and charging systems; Walsh 1995).

Ultimately, liberalization in the public sector aims at "reinventing government" / “banishing bureaucracy” (Osborne and Gaebler 1993; Osborne and Plastrik 1997). Some of the goals are familiar, even if they are articulated in non-microeconomic terms: Competitive government, customer-driven government, enterprising government, market-oriented government, mission-driven government and resultsoriented government. Other terms have wider connotations than those commonly encountered in the political economy literature: anticipatory government (emphasizes prevention rather than cure), catalytic government (separates "steering" / policy \& regulatory from "rowing" / service delivery \& compliance functions), communityoriented government (empowering rather than serving), and decentralizing government (favoring participation \& teamwork over hierarchy). There is no evidence that this is the overall direction in which liberalization is progressing in Hong Kong.

The divestiture by the public sector of a particular asset may follow a number of routes (Mayer and Meadowcroft 1985; Bailey 1995; Bailey 1999; Bailey 2004). Public floatation on the Stock Exchange is often resorted to. A trade sale (where the asset is acquired by a single firm or consortium) and a placement (with a group of investors) are other frequently used divestiture methods. A management or employee buyout is also occasionally relied upon. An alternative to an asset sale is a long-term lease (where, instead of transferring an asset's title to a private party via a sale, the government leases or "rents" the facility to a private party for a specified number of years; payment, maintenance, and operational requirements are spelled out in the 
lease agreement; at the expiration of the lease, the government has the right to resume full control of the facility; such an arrangement should not be confused with a franchise, or the granting of an exclusive right to a private party to provide a service within a certain geographical area).

A new privatization technique is a public-private asset swap, which features an exchange of an asset currently held by the government either for a comparable asset or for an agreement by the private party to develop a comparable asset (in such circumstances, governments swap valuable assets which they cannot utilize fully for facilities that are sufficient for public purposes). Value capture transactions have had a longer history, but they have until recently not been taken advantage of on a large scale. They normally allow the government to capture the value realized following the completion of an infrastructure project (by insisting on up-front concession payments or commitments based on the projected future value to be realized by the private party; by sharing directly in the property appreciation as it is realized by the private party after the project comes to fruition; by establishing tax increment or special-assessment districts). A typical example would be property adjacent to a road that opens up development opportunities.

Governments may also opt for "self-help," which involves the transfer of an asset to a non-profit organization (e.g., community groups or neighborhood organizations may assume control over a local park). They may take this notion further and seek the assistance of volunteers in the provision of services. Last but not least, governments may simply cease exercising responsibility for a certain function, paving way for an entry by a private party, which is known as "commercialization" or "service shedding." Again, a rather narrow range of privatization methods has been observed in Hong Kong. Public floatations have been the dominant element in the picture and long-term leases have been the technique of choice for land sales. Asset swaps are virtually unheard of, genuine value capture transactions are a rare phenomenon, and so are self-help, volunteer programs and commercialization / service shedding. Divestitures are seldom undertaken through trade sales, placements, or management / employee buyouts. 
Popular impressions notwithstanding, the effects of privatization are multidimensional in nature (Table 3). Public examination of the issue often focuses on short-term/static efficiency rather than that of the long-term/dynamic variety. There is also a tendency to accord much greater attention to technical, as distinct from allocative, efficiency (the former emphasizes the desirability of providing the output demanded by consumers at the lowest possible cost, subject to the technical constraints of production; the underlying assumption is that one cannot redeploy the inputs and obtain more output of one good without reducing the output of another; the input configuration is thus efficient; the latter requires that firms generate the level, mix, and quality of output at a price where it is not possible to realign the outputs of the economy and make one consumer better off without making another worse off; the corollary is that all potential gains from trade need to be exhausted). A lack of balance between technical and allocative efficiency may lead to policies geared toward cost-cutting rather than ones seeking a closer fit between prices and costs (Jackson and Price 1994).

The "short-termism" exhibited in addressing efficiency concerns reflects this syndrome and compounds the problem. It manifests itself in the preoccupation with the narrow question of ownership, or the most optimal short-term utilization of productive resources. This is the issue of static efficiency. However, beyond such a limited time horizon, the effectiveness of investment in new productive capacity, or dynamic efficiency, must duly be taken into consideration. Specifically, from a longterm perspective, efficiency cannot be achieved unless new investments are based on "correct" prices and the transfer of property rights from the public to the private sector in its various forms must be predicated on this notion. The implication is that privatization should be conceived as a process involving a wide array of institutional reforms rather than merely the change of ownership over assets. This is acknowledged in the academic/professional literature, albeit by no means adequately, but is often overlooked in practice (Jackson and Price).

The argument for conceptualizing privatization broadly, rather than in conventional (i.e., narrow) terms, was put forward earlier in the paper. In relation to dynamic efficiency, it is important to stress not the desirability of a comprehensive institutional overhaul per se, but the significance of strategies designed to enhance the 
effectiveness of the functioning of the price mechanism, where appropriate. The process of implementing such strategies is an extended and multi-faceted one. It normally precedes specific privatization projects and features a systematic effort to come to grips with the pricing of public output (i.e., proper use of user charges and fees; Ott and Harley 1991; Adam, Cavendish, and Mistry 1992; Jackson and Price 1994; Bailey 1995; Bailey 1999; Dollery and Wallis 2001; Bailey 2004).

Efficiency, whether technical or allocative, static or dynamic, should not be the sole factor driving policy decisions. Distributive justice is another crucial element in the picture (Table 3). As Okun (1975) has aptly pointed out, there is often a trade-off between efficiency and equity and the strategic balancing act may pose serious challenges in a moderate/slow growth environment. One cannot avoid the issue of the impact of privatization on the short-term distribution of income. Perhaps more fundamentally, especially if pursued consistently and on a large-scale, privatization may affect materially the distribution of wealth by inducing shifts in the structure of property rights and corresponding changes in entitlement to income (Jackson and Price 1994).

By the same token, macroeconomic variables such as growth, inflation, and unemployment are inevitably influenced by institutional re-engineering in general and deep changes in intersectoral relationships in particular (Table 3). To the extent that the revenues generated via privatization are employed to repay debt, replace tax revenues, or are offset against new borrowing, then this can have tangible macroeconomic consequences over the short term. Looking farther, it is questions of structural adjustment that loom large on the policy agenda. The crux of the matter obviously is whether privatization facilitates or hinders responses to internal and external shocks. This is an essential consideration for policy makers in an open economy setting (Siebert 1992; Jackson and Price 1994; Giersch 1997; Schipke 2001).

(Insert Table 3 about here)

The repercussions of privatization are not invariably favorable from a public interest perspective. The effects on distributive justice require careful scrutiny in most 
circumstances. In recent years, a modest intellectual backlash against the phenomenon has been witnessed and it has become selectively "fashionable" to question its benefits widely rather than just express mild concerns about the impact on the distribution of income and wealth (Nonneman 1996; Feigenbaum, Henig, and Hamnett 1998; Letza, Smallman, and Sun 2004). The attempts at "deconstruction" cannot be portrayed as entirely successful and the case for privatization on traditional grounds (efficiency and macroeconomic stabilization) remains largely intact, other things being equal. Nevertheless, the issue of distributive justice needs to be addressed earnestly in specific contexts, if the nature and scope of the undertaking merits such a stance, and the more concrete benefits should never be taken for granted. One does not have to side instinctively with the critics, but there is enough ambiguity in the relevant data to suggest that privatization should normally be approached with a "constructively sceptical" mindset (Jackson and Price 1994; Bailey 1995; Bailey 1999; Bailey 2004).

In Hong Kong, the focus has been mostly on technical/static efficiency and short-term stabilization. Dynamic efficiency has not been overlooked altogether in that the government has generally endeavored to promote competition in areas where privatization has been pursued in a meaningful fashion, transport being a case in point. Be that as it may, the pricing of services, before and following privatization, has not been handled in a systematic manner and progress toward a comprehensive competition policy has been painfully slow. Nor have modern regulatory structures been established across-the-board to insure that dynamic efficiency can be attained consistently over time (Mushkat and Mushkat 2005c). Such structures also have a role to play in contributing to long-term macroeconomic stabilization, a goal that has not been incorporated explicitly into the privatization agenda and whose full realization probably requires a bolder (in terms of breadth, depth, and pace) strategy of public sector liberalization.

Issues of distributive justice have been accorded scant attention, other than in relation to housing. This is hardly surprising as Hong Kong fits the paradigm of a "neoliberal state" (Suleiman and Waterbury 1990; Clarke and Pitelis 1993; Nonneman 1996; Feigenbaum, Henig, and Hamnett 1998). Its modus operandi reflects the assumption that the ultimate aim of development - eradication of poverty and improved welfare - 
is best achieved through economic growth and that in order to enjoy healthy economic growth it is preferable to rely on free-market forces than on state intervention. However, it should be noted that other neoliberal states, although perhaps less unequivocally so, are not altogether oblivious to the distributional consequences of individual projects or set of projects. Another point worth noting in this context is that there has been virtually no criticism, whether general or specific, of privatization in Hong Kong. Notwithstanding the putative merits of "rolling back the frontiers of the state," this is an undesirable state of affairs in that it might breed complacency, lead to policy mistakes, and prevent decision makers from identifying (where appropriate) alternatives to traditional-style divestitures.

Academic students of the phenomenon have recently ventured beyond the descriptive and normative aspects of privatization and have explored it widely from a political angle. The writings of public choice theorists stand out in this respect. They argue compellingly that one can neither fully understand the privatization dynamics nor offer effective institutional prescriptions without acknowledging that actors involved in the process are driven to a considerable extent by their own interests rather than engaged altruistically in a quest to maximize the welfare of the community-at-large. This manifest itself throughout the political arena, including the executive/ bureaucratic and legislative arms of government, rather than merely in the peculiar domain of pressure group activity (Caves 1990; Suleiman and Waterbury 1990; Clarke and Pitelis 1993; Giersch 1997; Feigenbaum, Henig, and Hamnett 1998).

The public choice factor does not feature meaningfully in discussions of privatization in Hong Kong, even at the academic level. The oversight does not imply that it irrelevant. For instance, the territory's two most senior public officials asserted, in an informal exchange on the subject with one of the authors, that a major impediment to speedy privatization of government departments and equivalent is the stiff resistance by employees. The corollary, from a public choice standpoint, is that the latter may have "captured" the organizational units in question. Special interest resistance, which may fall short of capture, comes into play in other forms as well (Mushkat and Mushkat 2003; Mushkat and Mushkat 2005a). It may be possible to minimize the difficulties to which this apparently gives rise by opting for less threatening (to employees) forms of privatization (e.g., public-private partnerships) and redesigning 
key parts of the institutional architecture (e.g., establishing autonomous/"apolitical" regulatory bodies). Clearly, however, the problem has to be diagnosed properly first.

\section{Conclusion}

Unlike many countries - notably India, Japan, and Taiwan in the region that it serves as a provider of intermediary services - Hong Kong does not have to confront the privatization challenge with a sense of urgency. While its government may not be the self-restrained peripheral player affectionately depicted by some commentators enamored with its supposedly unshakable devotion to capitalist principles, it nevertheless continues to act principally as a modest-size facilitator of private sector initiative in an open and flexible economic environment. This is certainly the case by international standards. Moreover, Hong Kong is in the fortunate position to have accumulated substantial fiscal surpluses, which have not been depleted seriously during the "lean years" following the 1997/98 Asian financial crisis. The robust recovery that has coincided with the post-2003 global upturn and the adoption of various Hong Kong-friendly measures by the central government in Beijing has propelled the fiscal balance firmly into positive territory. Hong Kong may thus "muddle through" comfortably on the privatization front.

That said, the argument cannot be stretched too far. The strength of the current upswing reflects, albeit not exclusively, special cyclical factors whose influence may not prove long-lasting. As a mature, service-based economy, Hong Kong is destined to expand at a more moderate rate than witnessed at the mid-point of the present decade. Demographic constraints, not addressed so far imaginatively and vigorously by the government, may turn out to be another strong headwind in this respect. The potentially fragile public revenue system, which has outlived its usefulness but has remained reform-proof in the face of rhetoric signaling its imminent demise, may not be able to withstand the pressures unleashed by such socio-economic forces and institutional rigidities. Privatization is not a panacea, but it may provide some relief at delicate junctures and reinvigorate the supply-side of the economy in the long run, rendering it more resilient and less vulnerable from a fiscal perspective. 
The relationship between privatization and the development of civil society also should not be overlooked. In the appropriate circumstances, the former may help to revitalize the latter (Suleiman and Waterbury 1990; Clarke and Pitelis 1993; Nonneman 1996; Feigenbaum, Henig, and Hamnett 1998). The reason lies in the fact that privatization is, by definition, an antidote to the "nanny state." If pursued consistently, on a sufficiently large scale, and in a way that displays sensitivity toward questions of distributive justice, it may encourage communities to become more selfrelient and less dependent on government direction. A flatter and more decentralized bureaucratic structure, conducive to the growth of civil society, is another possible byproduct of privatization. Hong Kong offers an interesting mixture of private (individual and corporate) initiative and generally well-functioning government infrastructure, but without a vibrant civil society acting as a bridge between the two (Lo 2002). Privatization could arguably contribute indirectly to the strengthening of this fledgling component.

Our analysis suggests that the performance may not match the promise. Hong Kong may qualify as a model neoliberal state, from a comparative standpoint, but it is hardly an aggressively reforming one. The type of radical institutional restructuring observed elsewhere (Australia, New Zealand, United Kingdom, and the United States) at various junctures is not likely to be contemplated, let alone followed in practice. One senses a satisfaction with the status quo and a preference for "swimming with the tide" produced by vested interests rather than leaning against it. Moreover, deep and rapid reforms may not be easy to undertake in the post-1997 political setting. The prevalence of external (China) and internal (institutional fragmentation and lack of grass-roots support) constraints militates against decisive action (Scott 2000; Lo 2002; Burns 2004; Scott 2005).

The handling of privatization also seems to expose some inherent weaknesses of government policy making. The task has obviously not been addressed in a "rationalcomprehensive" fashion. Indeed, there is no compelling evidence to indicate that it has even been managed in accordance with the "disjointed incrementalism" model of organizational problem solving (unless the disjointed element of the formula is allowed to dominate the incremental one). As stated earlier, the government is committed to privatization as a strategic goal and, to paraphrase Kingdon (2002), 
when an appropriate "window" opens, or the opportunity presents itself, it moves forward. However, the movement does not appear driven by a coherent vision and to be orchestrated in a logically consistent manner. Quite the contrary, the experience conjures up images of Kingdon's (2002) "garbage can model," which likens public decision making to actions of a magician who reaches inside a black hat and pulls out a rabbit.

Specifically, the segment of the policy environment in which privatization choices are made may well resemble an "organized anarchy." The government seems to tackle one strategic item at a time, on an ad hoc basis, and without seeking inspiration from a thoroughly explored, carefully tested and wide-ranging blueprint. As the recent proposal to integrate underground and overground rail services illustrates, there is no determined effort to arrive at the "best" configuration. Rather, the relevant decision makers normally embrace an option that "satisfices," or that is deemed to be "good enough" in the specific context in which it is considered. The process probably does not display sufficient continuity/smoothness over time to qualify as a form of incrementalism (again, other than one of a distinctly disjointed variety).

A rather striking feature of the situation is the narrow path followed in terms of the ends pursued, means adopted, linkages (between the two sets) identified, and variables explored. While privatization can scarcely be portrayed as an unfamiliar problem, it is not necessarily a "well-structured" one. It may at best qualify as a "moderately-structured" problem and may even have the attributes of the "illstructured" variant (Dunn 1994). If this assumption is valid, policy analysts/managers should be engaged in "a never ending discourse with reality, to discover yet more facts, more dimensions of action, more opportunities for improvement" (Derry 1984: 6-7). This means pushing the "boundaries" of the problem rather than shrinking them. The Hong Kong experience with privatization has arguably not conformed to that ideal, possibly depriving the community of institutional choices with the potential to enhance its welfare.

\section{Table 1}

\section{The Payer-Provider Split}




\begin{tabular}{ll|c|c|}
\multicolumn{1}{c}{} & \multicolumn{1}{c}{ Public } & Private \\
\cline { 3 - 4 } THE PAYER & Public & 1 & 2 \\
\cline { 3 - 4 } & Private & 3 & 4 \\
\cline { 3 - 4 } & &
\end{tabular}

Table 2

Ownership and Market Structure

\begin{tabular}{|l|c|c|c|}
\hline \multicolumn{3}{|c|}{ MARKETS } \\
\cline { 3 - 4 } OWNERSHIP & & Monopoly & Competitive \\
\cline { 3 - 4 } & Public & A & B \\
& Private & C & D \\
\hline
\end{tabular}

1. $\mathrm{D}$ is superior to $\mathrm{A}$, where $\mathrm{D}$ represents private ownership and a competitive product market.

2. $\mathrm{D}$ is superior to $\mathrm{C}$ reflecting the standard economic view which favors competition.

3. D is equal to, or superior to, B. A review of the evidence suggests that under competition, private firms are likely to be superior to public sector firms.

4. B is superior to A, reflecting the role of competition.

5. C is superior A, reflecting in a non-competitive environment the policing role of private capital markets.

6. $\mathrm{B}$ is superior, inferior or equal to $\mathrm{C}$ (inconclusive) depending on the relative strengths of competition and ownership.

Table 3

Economic Effects of Privatization

\begin{tabular}{|l|l|l|}
\hline & SHORT TERM & LONG TERM \\
\hline EFFICIENCY & Static Efficiency & Dynamic Efficiency \\
\hline DISTRIBUTION & Distribution of Income & Distribution of Wealth \\
\hline STABILIZATION & $\begin{array}{l}\text { Adjustments to Cyclical } \\
\text { Fluctuations }\end{array}$ & Structural Adjustments \\
\hline
\end{tabular}




\section{References}

Adam, C., W. Cavendish, and P.S. Mistry (1992) Adjusting Privatization (London: Currey).

Anderson, T.L. and P.J. Hill (1996) The Privatization Process (Lanham: Rowman and Littlefield).

Ash, R. et al. (2003) Hong Kong in Transition (London: Routledge Curzon).

Bailey, S.J. (1995) Public Sector Economics (Basingstoke: Macmillan).

Bailey, S.J. (1999) Local Government Economics (Basingstoke: Macmillan).

Bailey, S.J. (2004) Strategic Public Finance (Basignstoke: Palgrave Macmillan).

Baumol, W. J. (1967) Macroeconomics of unbalanced growth, American Economic Review, 57(3): pp. 415-426.

Bird, R.M. (1971) Wagner's "law" of expanding activity, Public Finance, 26(1): pp. $1-26$.

Bollard, A.E. and R.A. Buckle (1987) Economic Liberalization in New Zeland (Wellington: Allen and Unwin).

Bollard, A.E. (1992) New Zealand (San Francisco: ICS Press).

Boston, J., et al (1991) Reshaping the State (Auckland: Oxford University Press).

Brewer, B. and A. La Grange (2001) Reforming Public Housing in Hong Kong (Hong Kong: Department of Public and Social Administration, City University of Hong Kong).

Burns, J.P. (2004) Government Capacity and the Hong Kong Civil Service (Oxford: Oxford University Press).

Butler, S. (1991) Privatization for public purposes, in W.T. Gormely (Ed) Privatization and its Alternatives (Madison: University of Wisconsin Press): pp. 1724.

Carter, D. (1965) Power in Washington (New York: Random House).

Caves, R.E. (1990) Lessons from privatization in Britain, Journal of Economic Behavior and Organization, 13 (1): pp. 145-169. 
Cheek-Milby, K. (1995) A Legislature Comes of Age (Hong Kong: Oxford University Press).

Chen, E.K.Y. (1984) The economic setting, in D.G. Lethbridge (Ed) The Business Environment in Hong Kong (Hong Kong: Oxford University Press): pp. 1-51.

Cheng, L.K. and R.Y.C. Wong (1997) Port Facilities and Container Handling Services (Hong Kong: City University of Hong Kong Press).

Cheng, L.K. and C. Wu (1998) Competition Policy and Regulation of Business (Hong Kong: City University of Hong Kong Press).

Cheng, T.Y. (1982) The Economy of Hong Kong (Hong Kong: Far East Publications).

Clarke, T. and C. Pitelis (1993) The Political Economy of Privatization (London: Routledge).

Cobb, R.W. and C.E. Elder (1983) Participation in American Politics (Baltimore: John Hopkins University Press).

de Mesquita, B.B., D. Newman, and A. Rabushka (1985) Forecasting Political Events (New Haven: Yale University Press).

de Mesquita, B.B., D. Newman, and A. Rabushka (1996) Red Flag Over Hong Kong. (Chatham: Chatham House).

Derry, D. (1984) Problem Definition in Policy Analysis (Lawrence: University Press of Kansas).

Dollery, B.E. and J.L. Wallis (2001) The Political Economy of Local Government (Cheltenham: Elgar).

Dunn, D.N. (1994) Public Policy Analysis (Englewood Cliffs: Prentice Hall).

Dye, T.R. and H. Ziegler (1981) The Irony of Democracy (Monterey: Brooks/Cole).

Easton, B.H. (1989) The Making of Rogernomics (Auckland: Auckland University Press).

Feigenbaum, H., J. Henig, and C. Hamnett (1999) Shrinking the State (Cambridge: Cambridge University Press).

Giersch, H. (1997) Privatization at the End of the Century (Heidelberg: Springer).

Hall, C. (1996) The Uncertain Hand (Hong Kong: Chinese University Press).

Ho, H.C.Y. and L.C. Chau (1989) The Economic System of Hong Kong (Hong Kong: Asia Research Center). 
Ho, L.S. (1997) Health Care Delivery and Financing in Hong Kong (Hong Kong: City University of Hong Kong Press).

Holland, M. and J. Boston (1990) The Fourth Labor Government (Auckland: Oxford University Press).

Jackson, P.M., and C. Price (1994) Privatization and Regulation (Harlow: Longman).

Jao, Y.C. (2001) The Asian Financial Crisis and the Ordeal of Hong Kong (Westport: Quorum Books.

Kingdom, J.W. (2002) Agendas, Alternatives, and Public Policies (New York: Longman).

Kwong, J.A. (1990) Market Environmentalism (Hong Kong: Chinese University Press).

Kwong, K.S. (1988) Toward Open Skies and Uncongested Airports (Hong Kong: Chinese University Press).

Lam, P.L. (1997) Competition in Energy (Hong Kong: City University of Hong Kong Press).

Lam, P.L. and Y.C. Chan (1997) Privatizing Water and Sewage Services (Hong Kong: City University of Hong Kong Press).

Lam, P.L. and S. Chan (2000) Competition in Hong Kong's Gas Industry (Hong Kong: Chinese University Press).

Lane, J.E. (2000) The Public Sector (London: Sage).

Lethbridge, D. and S.H. Ng (2000) The Business Environment of Hong Kong (Oxford: Oxford University Press).

Letza, S.R., C. Smallman, and X. Sun (2004) Reframing privatization, Policy Sciences, 37(2): pp. 159-183.

Lo, S.H. (2002) Governing Hong Kong (New York: Nova Science).

Mayer, C.P. and S.A. Meadowcroft (1985) Selling public assets, Fiscal Studies, 6(4): pp. $42-56$.

Meyer, D.R. (2000) Hong Kong as a Global Metropolis (Cambridge: Cambridge University Press).

Mueller, M. (1991) International Telecommunications in Hong Kong (Hong Kong: Chinese University Press).

Mushkat, M. (1990) The Economic Future of Hong Kong (Boulder: Rienner). 
Mushkat, M. and R. Mushkat (2003) The political economy of constitutional conflict in an externally-constrained environment, Journal of Malaysian and Comparative Law, 30 (1\&2), pp. 15-36.

Mushkat, M. and R. Mushkat (2004) The political economy of constitutional conflict in Hong Kong, Tilburg Foreign Law Review, 11 (2), pp. 756-781.

Mushkat, M. and R. Mushkat (2005a) Conversationalism, constitutional economics, and bicameralism, Asian Journal of Political Science, 13(1), pp. 23-50.

Mushkat, M. and R. Mushkat (2005b) The political economy of recasting the political debate in Hong Kong, International Journal of Applied Philosophy, 19(1), pp. 63-72.

Mushkat, M. and R. Mushkat (2005c) The political economy of non-majoritarian institutions, Journal of East Asian Affairs, 29(1), pp. 143-164.

Nonneman, G. (1996) Political and Economic Liberalization (Boulder: Rienner).

Okun, A. (1975) Equality and Efficiency (Washington: Brookings Institution).

Osborne, D. and T. Gaebler (1993) Reinventing Government (New York: Plume Books).

Osborne, D. and P. Plastrik (1997) Banishing Bureaucracy (Reading: Addison Wesley).

Ott, A.F. and K. Hartley (1991) Privatization and Economic Efficiency (Aldershot: Elgar).

Peacock, A.T. and J. Wiseman (1961) The Growth of Public Expenditure in the United Kingdom (Princeton: Princeton University Press).

Peebles, G. (1988) Hong Kong's Economy (Oxford: Oxford University Press).

Rabushka, A. (1973) The Changing Face of Hong Kong (Washington: American Enterprise Institute).

Rabushka, A. (1976) Value for Money (Stanford: Hoover Institution Press).

Rabushka, A. (1979) Hong Kong (Chicago: Chicago University Press).

Schipke, A. (2001) Why Governments Divest? (Berlin: Springer-Verlag).

Scott, I. and J.P. Burns (1988) The Hong Kong Civil Service (Hong Kong: Oxford University Press).

Scott, I. (2000) The disarticulation of Hong Kong's post-handover political system, China Journal, 22(43), pp. 29-53. 
Scott, I. (2005) Public Administration in Hong Kong (Singapore: Marshall Cavendish).

Siebert, H. (1992) Privatization (Tubingen: Mohr).

Suleiman, E.N. and J. Waterbury (1990) The Political Economy of Public Sector Reform and Privatization (Boulder: Westview Press).

Sung, Y.W. (1991) The China-Hong Kong Connection (Cambridge: Cambridge University Press).

Sung, Y.W. (2002) The Emergence of Greater China (Basingstoke: Palgrave).

Walsh, K (1995) Public Services and Market Mechanisms (Basingstoke: Macmillan).

Wong, R.Y.C. (1998) On Privatizing Public Housing (Hong Kong: City University of Hong Kong Press).

Woronoff, J. (1980) Hong Kong (Hong Kong: Heinemann).

Youngson, A.J. (1982) Hong Kong (Hong Kong: Oxford University Press). 